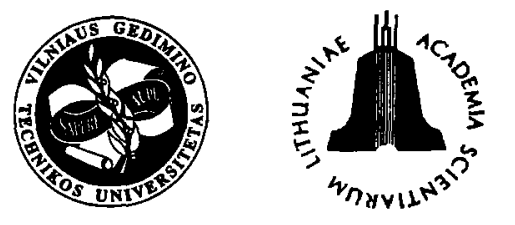

JOURNAL OF CIVIL ENGINEERING AND MANAGEMENT

http:/www.vtu.lt/english/edition

2002, Vol VIII, No 1, 42-48

\title{
PECULIARITIES OF CALCULATING THE CYCLIC STRENGTH OF IMPORTANT THREADED JOINTS
}

\author{
Mindaugas Leonavičius ${ }^{1}$, Algimantas Krenevičius ${ }^{2}$, Stanislav Stupak ${ }^{3}$, Marijonas Šukšta ${ }^{4}$ \\ Dept of Strength of Materials, Vilnius Gediminas Technical University, \\ Sauletekio al. 11, LT-2040 Vilnius, Lithuania
}

Received 28 June 2001; accepted 20 Nov 2001

\begin{abstract}
The calculation of the strength of important threaded joints is started by defining the minimum size of the cross-section of bolts (studs). Then the static and cyclic strength is tested. The studs of the demountable joints of nuclear power equipment are calculated in accordance with the norms of the Russian Federation and the ASME Code. The calculation methods coincide in essence, they are based on similar limit states; however, there also some differences exist. The authors investigate and compare both methods in their work. There is a brief analysis of calculation methods in the article.

For closer definition of standards and their substantiation the authors used experimental and theoretical investigations performed at Laboratory of Strength Mechanics of Vilnius Gediminas Technical University.

In order to develop a uniform cyclic strength and shakedown calculation procedure for critical threaded joints, a completely new calculation of a progressive profile change is recommended to be performed before the calculation of cyclic strength. The results have been used in the development of calculation standards for nuclear power equipment, in designing mineral grinding machines and evaluating their residual resource.
\end{abstract}

Keywords: threaded joints, bolt, cyclic strength, shakedown.

\section{Introduction}

Research on threaded joints has been started at the Vilnius Civil Engineering Institute (VISI) since 1971; it was commissioned by Moscow Institute of Machine Science. The Russian Federation (RF) standards published in 1973 [1] were insufficiently substantiated by theoretical and experimental investigations. The goal of the research performed at the Department of Strength of Materials of the VISI was to specify more accurately, ground and replenish the standards for calculating the operating equipment at nuclear power stations. Based on these investigations, new standards have been elaborated and published [2]; in them, calculation methods of threaded joints have been improved and simplified aiming at a more convenient application in engineering practice. The first research was supervised by R. Popilskis. Continuous support and consultations were rendered by such wellknown specialists in the mechanics of deformable bodies as S. Serensen, R. Shneiderovitch, N. Machutov, V. Filatov, M. Daunys, etc. Rector of the VISI Academician A. Cyras took a continual interest in the work performed. Since 1972, different investigations were su-

\footnotetext{
1 E-mail: minleo@fm.vtu.lt

2 E-mail: ma@fm.vtu.lt

3 E-mail: stupakas@adm.vtu.lt

4 E-mail: marsu@fm.vtu.lt
}

pervised by V. Kagan. Some research on the resistance of threaded joints to cyclic disintegration was guided by A. Krenevičius, A. Speičys and M. Leonavičius. The materials, of which threaded joints are manufactured, the determination of their static and cyclic properties, regularities of crack formation and expansion in joints of different constructions by using the theory of mechanical destruction were the subjects of the main works performed up to 1990 . In 1985, M. Šukšta and M. Leonavičius started investigations connected with the possibility of adapting threaded joints. A. Čižas and S. Stupak have investigated, by the method of finite elements, the state of stress and strain and the distribution of stresses. At present a research is being carried out at the Laboratory of Strength Mechanics according to the international programme intended for increasing the durability (longevity) of mining industry equipment.

The methods of experimental research included the known approaches [3] and were being constantly improved in order to ensure such a loading of threaded joints tested which corresponds at most to actual working conditions. The analysis of developing the stress state and crack formation presented in the works [4-18] shows the resistance to cyclic disintegration, the complexity of adaptation process and regularities disclosed by experimental and theoretical research. The present article reviews some peculiarities of investigating and calculating threaded joints stressed, and cyclically tensioned or bended. 


\section{Calculation of minimum cross-section}

Threaded joints applied for connecting the covering of a high-pressure vessel and its body are calculated ac-cording to RF standards [2] (further they may be marked as AEDS - atomic engineering design standards) and according to ASME code [14, 15] (further may be marked as ASME - the American Society of Mechanical Engineers boiler and pressure vessel code, an internationally recognised code).

The cross-section area $A_{b 1}$ of all studs according to the thread cavity or other smaller cross-section must be [14-15]:

$$
A_{b 1} \geq \max \left(A_{m 11}, A_{m 21}\right)=\max \left[\frac{\left(W_{m 11}\right)_{D}}{S_{b}}, \frac{W_{m 21}}{S_{a}}\right],
$$

here $S_{a}, S_{b}$ are the calculated intensity of compared tensions $S_{m}$ under the design and normal temperatures. The cross-section $A_{m 11}$ is determined according to the general stud tension $\left(W_{m 11}\right)_{D}$, when the design pressure $P_{D}$ :

$$
\left(W_{m 11}\right)_{D}=\frac{\pi}{4} \cdot G^{2} \cdot P_{D} \cdot\left(1+\frac{8}{G} \cdot b_{1} \cdot m_{1}\right),
$$

here $G$ is diameter of sealant; $b_{1}$ is half of the sealant effective width; $m_{1}$ is the coefficient depending on the sealant type and material. The cross-section area $A_{m 21}$ is determined by the condition of compaction caused by tension $W_{m 21}$

$$
W_{m 21}=\pi \cdot G \cdot b_{1} \cdot y,
$$

here $y$ is minimum calculated pressure in the sealant during the compaction. The force of tightening should be not less than $\max \left[\left(W_{m 11}\right)_{D}, W_{m 21}\right]$. Whether it is sufficient or not, it is determined during a hydrostatic testing.

It should be noticed that the calculated pressure $P_{D}$ does not depend on the pressure test conditions which are taken into account when calculating static and cyclic strength. Meanwhile, in calculations of pipe flange joints no attention is paid to the influence of loads resulting during the tests.

According to AEDS, the cross-section area of the studs should be:

$$
A_{b 2} \geq \max \left[\frac{\left(W_{m 12}\right)_{h}}{[\sigma]_{w h}}, \frac{\left(W_{m 12}\right)_{D}}{[\sigma]_{w D}}, \frac{W_{m 22}}{[\sigma]_{w a}}\right],
$$

here $[\sigma]_{w h},[\sigma]_{w D},[\sigma]_{w a}$ are allowable stresses (analogue of $S_{m}$ ) at corresponding temperatures.

If the pressure is $P_{D}$, the stress $\left(W_{m 12}\right)_{D}$ is determined according to the thermal expansion of intermediate details in the stud axis direction.

$$
\left(W_{m 12}\right)_{D}=\frac{\pi}{4} \cdot G^{2} \cdot P_{D} \cdot\left(1-\chi+\frac{4}{G} \cdot b_{2} \cdot m_{2}\right),
$$

here $b_{2}$ is the analogue of $2 b_{1} ; \chi$ is the loading coefficient depending on the mobility of sealant, stud, nut and other joining details.

The stress depending on calculated pressure:

$$
W_{m 22}=\pi \cdot G \cdot b_{2} \cdot q_{0},
$$

here $q_{0}$ is the analogue of $\mathrm{y}$ according to ASME.

The tightening force must be not less than $\max \left[\left(W_{m 12}\right)_{h},\left(W_{m 12}\right)_{D}, W_{m 22}\right]$. The methods for calculating pipe joints in RF standards do not take into account the general effect of bending and twisting (torsion) developed due to loading and thermal expansion. When comparing formulas (1), (2) and (3), according to ASME, with (4), (5), and (6), according to AEDS, as well as the peculiarities of pipe flange joints, a similarity of structure of the calculating formulas has been observed. However, analogous stresses in studs may differ. An analysis has disclosed that $A_{b 1} / A_{b 2} \geq 1,5$. One of the causes is the difference of allowable stresses $[\sigma]_{w}=R_{p 0,2}^{T} / 2$ and $S_{m}=\left(R_{p 0,2}^{T} / 3\right)\left(R_{p 0,2}^{T}\right.$ is conventional yield limit under the temperature discussed). When testing by pressure, the stress $\left(W_{m 12}\right)_{h}$ can result in value $A_{b 2}$. The difference of tightening is also observed according to ASME and AEDS.

\section{Calculation of static strength}

When performing a verifying static analysis, the cross-sections $A_{b 1}$ and $A_{b 2}$ may increase. The calculated cases are analysed according to [2]: normal service conditions; disturbed service conditions; break-down state, pressure testing. According to $[14,15]$, the following cases are analysed: design conditions (DL); service condition state A; level B; level C; level D; hydrostatic test. Under normal conditions (level DL and A) limits of stresses are normal. Until the conditions allow some deviations of atomic energy equipment state, limit stresses increase.

The stress limits are defined for different categories, stress category groups, and calculated cases. The stress categories groups according to AEDS: $\sigma_{m w}$ or $(\sigma)_{1 w}$ average stresses in the stud caused by a mechanical impact including tension; $(\sigma)_{3 w}$ the same because of a mechanical and thermal impact; $(\sigma)_{4 w}$ - maximum stresses due to mechanical and thermal impact in spite of a concentration of stresses calculated by tension, bending and torsion of the stud. If tightening is performed in such a way that tangential stresses develop, the $(\sigma)_{4 w}$ are calculated according to the hypothesis of maximum tangential stresses. The ASME stress categories are analogous, though they do not have a special marking.

Thus under comparable conditions the stud service loading corresponding to a separate limit of stress category groups is, by AEDS, not larger than by the ASME code. During tightening and especially during the pressure test overloads are possible, and they result in increased fatigue phenomena. It should be noted that the first ten hydrostatic tests, in accordance with [14, 15], are not taken into account when calculating the cyclic strength.

The stresses in studs due to seismic loads according to ASME are not taken into account if the seismic loads are attributed to the design level D. In this case the limits of stress category groups are valid. The comparison presented in [11] shows that the stress limits according to AEDS may change depending on condi- 
tions from $[\sigma]_{w} \approx 0,5 R_{p 0,2}^{T}$ (normal service conditions) up to $[\sigma]_{w} \approx 1,2 R_{0,2}$ (failure state). According to ASME, the comparative stresses $S_{m}$ may change from $R_{p 0,2}^{T} / 3$ (design conditions) up to strength limit $R_{m}^{T}$, only when $R_{m}^{T}>100 \mathrm{ksi}(689 \mathrm{MPa})$ of elastic calculation (level D).

The limits of stress categories for pipeline and vessel joints strength calculations, according to RF standards, are more conservative than those of the ASME code. Limitations for studs under seismic loading, according to [2], are also more conservative in comparison with $[14,15]$ (using level D limits).

\section{Calculation of cyclic strength}

Calculation of important threaded joints by ASME and AEDS is performed according to crack development. Therefore a special attention is given to the cracks appeared in the environment of this limit state. Evaluation of reliability and durability of joints is connected with the analysis of stresses and strains, with the investigations into kinetics of short cracks as well as in different factors stimulating or retarding this process.

In works $[7,8,11]$, peculiarities of calculating threaded joint cyclic strength are analysed, the RF standards and the ASME code are compared. The calculated stresses are determined in relation to the stress concentration (in the range of elasticity). For all calculated cases (normal service conditions, failure state, disturbed service conditions, testing by pressure), relatively elastic stresses beyond the elasticity limits have been adjusted. Maximum stresses $\left(\sigma_{F}\right)_{\max }$ and cyclic amplitude $\sigma_{a F}$ have been calculated. Namely they describe the process of loading during service and testing. The limits of local stress precising according to [2] and [14, 15] are different. According to the principle of local stress correction by using the equivalence of strain energies for an elastic or elastic-plastic model, larger stresses are obtained in the concentration zone. This difference increases when stresses are high and without a concentration. In this case [2] a method is applied which uses the stress concentration effective coefficient $k_{e f}$.

When calculating the theoretical stress concentration coefficient $k_{\sigma}$ by AEDS, the thread pitch $M$, the thread top rounding radius $R$, nut's type and height $\left(k_{s}\right)$, a possible difference of the stud's and body's material $\left(k_{w}\right)$

$$
k_{\sigma}=k_{s} \cdot k_{w}(1+1,57 \sqrt{M / R}) .
$$

If $\sigma_{a F}$ exceeds the elasticity limit and the thread rounding radius is specified, then $k_{e f}=k_{\sigma}$. When the profile is not strictly defined, $k_{e f}=1,2 k_{\sigma}$. If $\sigma_{a F}$ does not exceed the elasticity limit, then

$$
k_{e f}=1+q\left(k_{\sigma}-1\right)
$$

here $q \leq 1$ is coefficient of material concentration sensitivity. The effective stress concentration coefficient, according to [2], may be from 4 up to 6 . According to $[14,15]$, such coefficients may be larger or smaller than
4 if they are based on experimental research.

The empirical fatigue curve $[2,11]$ may be substantiated by experimental investigations:

$$
\sigma_{a F}=\sigma_{a p}+\sigma_{a c}=\frac{E^{T}\left(e_{e}^{T}-e_{m}\right)}{(4 N)^{m}}+\frac{R_{f}^{T}-\left(\sigma_{F}\right)_{\max }}{(4 N)^{m}-1},
$$

here $\sigma_{a p}$ is the component of relatively elastic stresses corresponding to the value of plastic strain; $\sigma_{a c}$ is the component of real stresses corresponding to the value of elastic strain (when $r=-1$ ); $E^{T}$ is elasticity module; $e_{c}^{T}$ is plasticity index depending on the cross-section contraction, $e_{m}$ is cycle average plastic strain; $R_{f}^{T}$ are real stresses of rupture; $N$ is number of cycles; $m$ is power index depending on strength limit. If cycle average stresses and strain are negative, the fatigue curve is used.

$$
\sigma_{a F}=\sigma \frac{E^{T} \cdot e_{e}^{T}}{(4 N)^{m}}+\frac{R_{f}^{T}}{(4 N)^{m}} .
$$

The local stresses have been defined, the asymmetry coefficient is refined

$$
r=\frac{\left(\sigma_{F}\right)_{\max }-2 \sigma_{a F}}{\left(\sigma_{F}\right)_{\max }}
$$

Fatigue curves, according to [14-15], are obtained when the concentration coefficient in the elastic area for metric threads equals 4 (stress allowance $n_{\sigma}=1,5$; cycle number allowance $n_{N}=3$ ), and in the elastic-plastic area it can be calculated by Neuber dependence (allowance $\left.n_{\sigma}=1,5 ; n_{N}=5\right)$ and it amounts to 5,5.

When calculating according to nominal stresses depending on pressure fatigue, allowance coefficients by [2] standards are obtained not so much conservative than those calculated by standards of $[14,15]$. However, a direct comparison of fatigue curves, when the cycle number does not exceed $10^{8}$, including an increase in concentration coefficients, shows that the allowable amplitude and number of cycles are specified more strictly according to AEDS requirements than to those of ASME.

By the standards of [2] the allowable number $[N]$ of cycles is defined by specifying the cycle number under certain stress cycle amplitude $\sigma_{a}$. It is performed into two ways: according to the calculated fatigue curves presented and by formulas if the cycle number does not exceed $10^{6}$

From four values calculated by formulas $(9,10)$, of the allowable cycle number $[\mathrm{N}]$, the smallest value is to be chosen.

The smaller values $n_{\sigma}$ and $n_{N}$ according to AEDS (compared to ASME) are based on a negligible probability of simultaneous disintegration of studs and the possibility of changing them under service conditions. The analysis performed in some works $[8,11]$ shows that it is possible to decrease $n_{\sigma}, n_{N}$ from 2 and 20 up to 1,5 and 5,7 respectively.

In the Laboratory of Strength Mechanics the research on threaded joints of steel 25XIM $\Phi(\mathrm{M} 110 \times 6$; $R_{p 0,2}^{20}=855 \div 366 \mathrm{MPa}$ and $\mathrm{M} 130 \times 6 ; R_{p 0,2}^{20}=830 \div 855$ 
$\mathrm{MPa}$ ) with a flat cut cavity when the coefficient of cycle asymmetry is 0,$09 ; 0,24 ; 0,1 ; 0$, was carried out. By taking apart and controlling periodically the studs and using the luminescent and magnetic method, the development of a crack was observed. Then the joints were assembled and loaded cyclically again. A threaded joint represented a system of stud-nut and stud-body (body substitute). The size of the crack was from 3 to $40 \mathrm{~mm}$ along the cavity perimeter.

Calculation of fatigue curves was performed with real and guaranteed steel properties: yield limit $R_{p 0,2}$, strength limit $R_{m}$, percentage cross-section reduction area $Z$; modulus of elasticity $E$. Average mechanical indices of M110×6 studs of 25 XIM $\Phi: R_{p 0,2}=921 \mathrm{MPa}$, $R_{m}=1032 \mathrm{MPa}, Z=58 \%, E=215 \mathrm{GPa}$. The studs M130×6: $R_{p 0,2}=844 \mathrm{MPa}, R_{m}=945 \mathrm{MPa}, Z=58 \%$, $E=215 \mathrm{GPa}$. Guaranteed indices of mechanical properties: $R_{p 0,2}=736 \mathrm{MPa}, R_{m}=883 \mathrm{MPa}, Z=45 \%$, $E=215 \mathrm{GPa}$. Calculating number $N_{11}$ according to AEDS and experimental cycle number $N_{21}$ are shown in Figs 1 and 2.

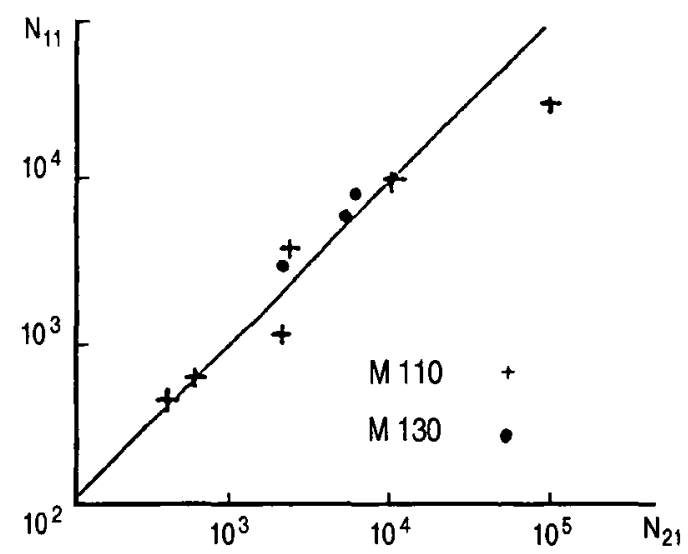

Fig 1. Calculated cycle number $N_{11}$ (AEDS) according to the crack threshold and experimental data $N_{21}$, steel 25XIMФ, real mechanical properties

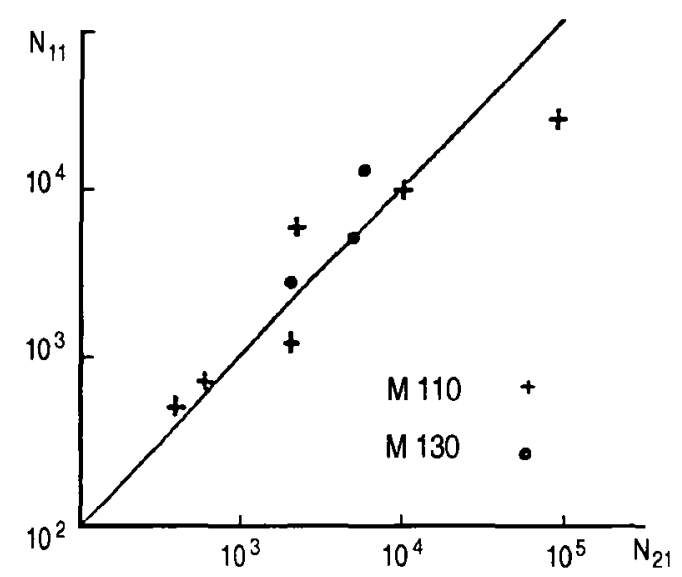

Fig 2. Calculated cycle number $N_{11}$ (AEDS) according to the crack threshold and experimental data $N_{21}$, steel $25 \mathrm{XIM} \Phi$, guaranteed mechanical properties
Calculating number $N_{11}$ according to ASME is compared with the experiment in Fig 3 (the design fatigue curve is composed when $n_{\sigma}=n_{N}=1$ ). The results show that the number of cycles according to $[14,15]$ is increased.

When calculating the allowable cycle number, it is possible to observe the conservativeness of ASME in comparison with AEDS when the number of cycles increases $[N]>300$, as shown in Fig 4 .

An analogous analysis has been performed using test results of threaded joints M52 (thread pitch $5 ; 4 ; 3 ; 2$; $1,5)$ of steel $38 \mathrm{XH} 3 \Phi \mathrm{A}$. The thread cavity is rounded off by the radius $0,144 M$, nut cross-section $1,56 d$ and height $1,7 d$.

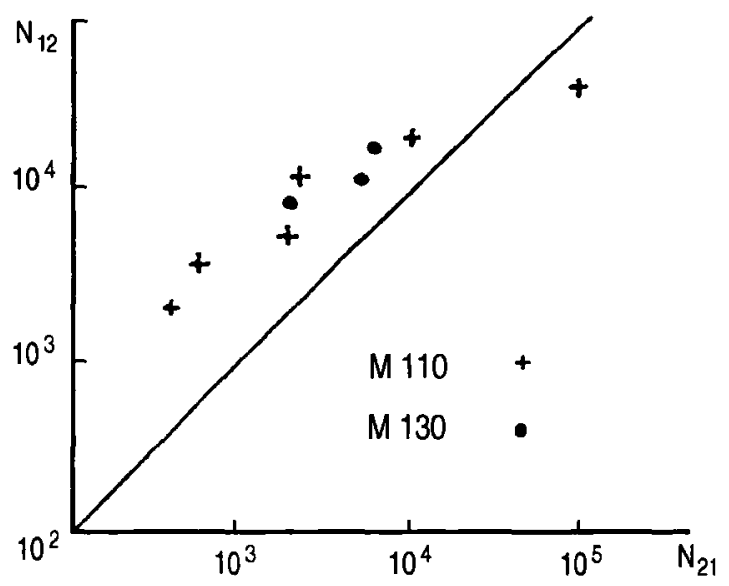

Fig 3. Calculated cycle number $N_{12}$ (AEDS) according to the crack threshold and experimental data $N_{21}$

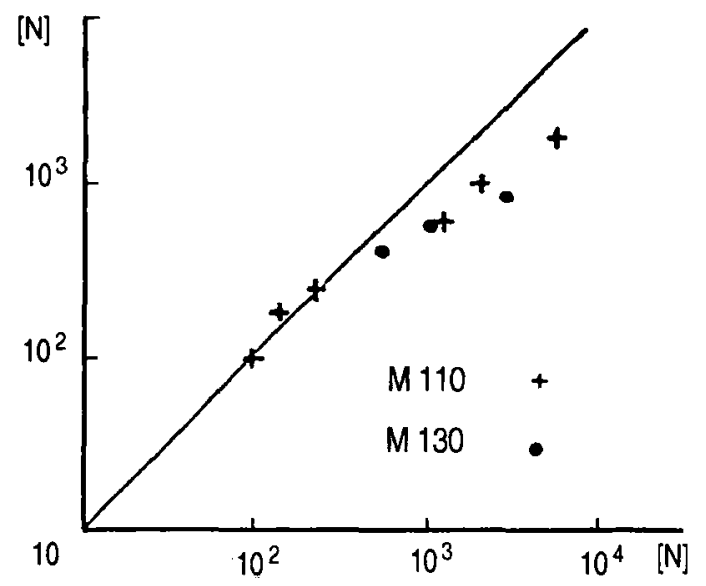

Fig 4. Allowable cycle number $[N]$ (AEDS), steel 25XIM $\Phi$, guaranteed mechanical properties by ASME code as well

The threaded joints have been tested according to the system nut-stud-nut, coefficient of cycle asymmetry 0,03 and 0,04 . Average indices of mechanical properties: $R_{p 0,2}^{20}=963 \mathrm{MPa} ; R_{m}^{20}=1063 \mathrm{MPa} ; Z^{20}=58 \%$; $E=215 \mathrm{GPa}$. Guaranteed mechanical indices $R_{p 0,2}^{20}=880 \mathrm{MPa} ; R_{m}^{20}=981 \mathrm{MPa} ; Z^{20}=35 \%$. In this 


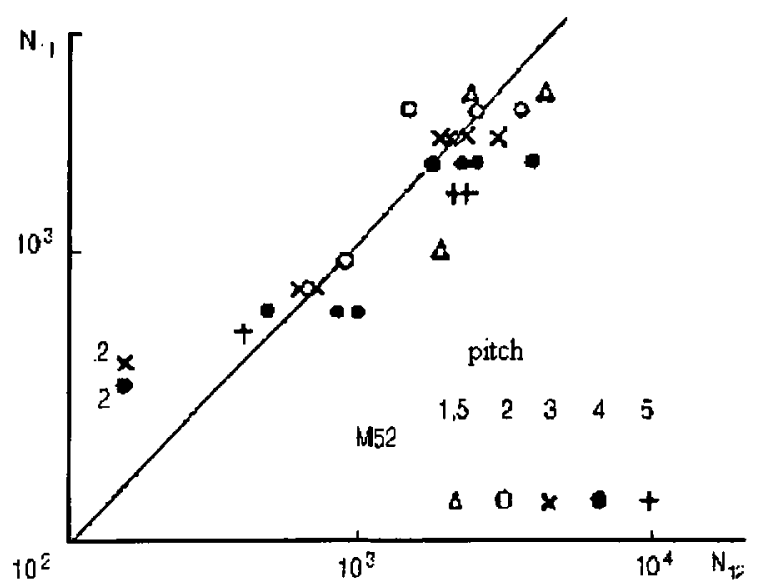

Fig 5. Calculated cycle number $N_{11}$ (ASME) according to the crack threshold and experimental data $N_{12}$, steel 38XHЗMФA, real mechanical properties

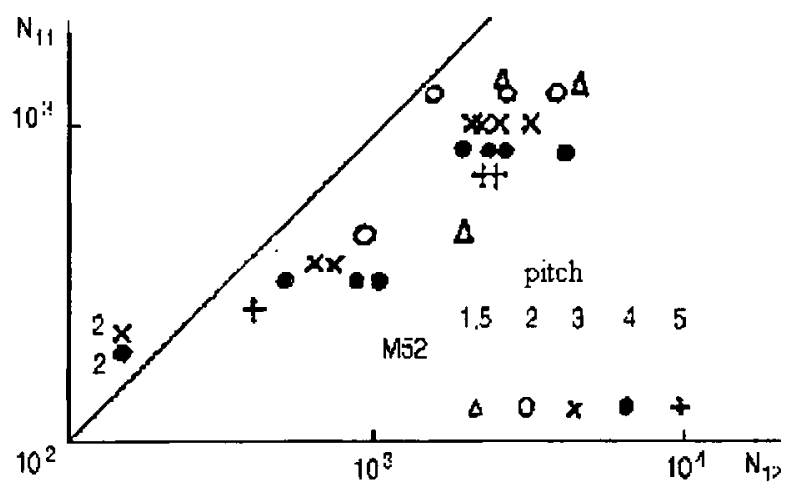

Fig 6. Calculated cycle number $N_{11}$ (ASME) according to the crack threshold and experimental data $N_{12}$, steel $38 \mathrm{XH} 3 \mathrm{MФA}$, guaranteed mechanical properties

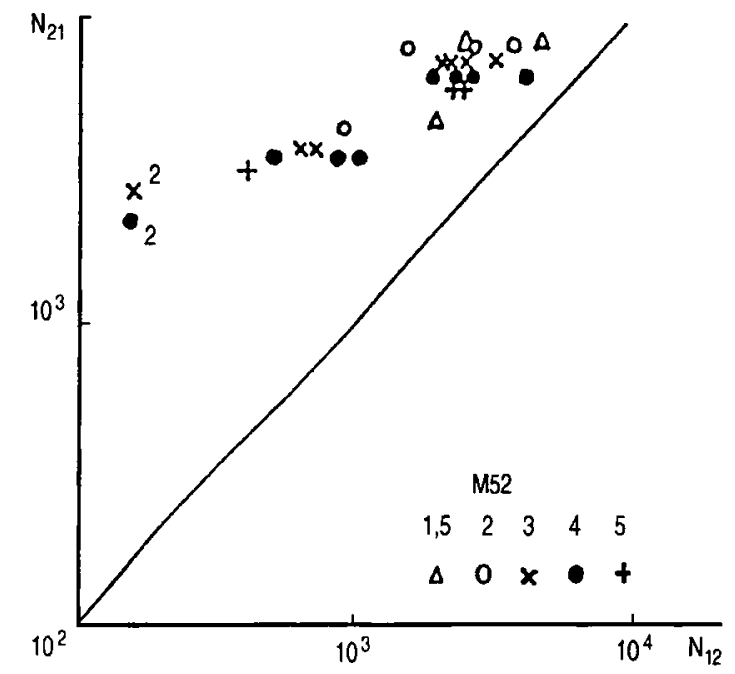

Fig 7. Calculated cycle number $N_{21}$ (ASME) and according to test data $N_{12}$, steel $38 \mathrm{XH} 3 \mathrm{M} \Phi \mathrm{A}$

case, $k_{e f}=4,62$ (by formula 8 ), when $k_{s}=0,9$ (this value was used for calculations according to ASME and AEDS). With the decrease of thread pitch, the durability has slightly increased.
A comparison of the calculated cycle number according to real and guaranteed mechanical properties and presented in Figs 5 and 6 shows a satisfactory coincidence of the results.

The calculated cycle number increases when calculating takes place according to ASME compared with the experimental data, as shown in Figs 7 and 8.

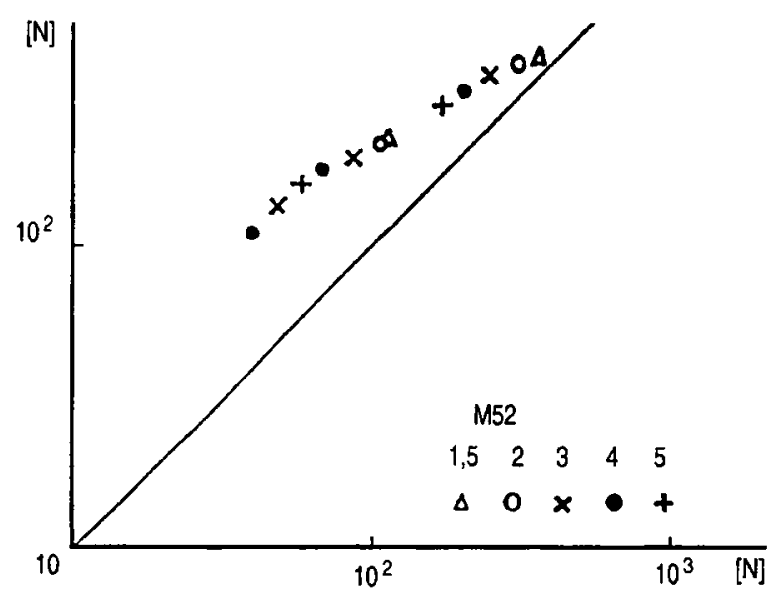

Fig 8. Allowable cycle number $[M]$ according to AEDS, guaranteed mechanical properties, and according to ASME code

The comparison of allowable stresses according to ASME and AEDS has shown a convergence of results, when $N=(2 \div 4) 10^{3}$ cycles, though up to this there is a considerable difference.

In the multicyclic region, under the same $\sigma_{a F}$ the allowable $[N]$ according to AEDS will be larger than that according to ASME. It depends on safety coefficients $n_{\sigma}=1,5$ according to AEDS and $n_{\sigma}=2$ according to ASME. In the low-cyclic region, the cycle number according to ASME increases, though it is not compensated by larger safety coefficients.

The experimental data show that a crack develops in an early loading stage and its position is localised; it makes easier to control the crack threshold and development. The results obtained and compared in Figs 1-5 show that the calculation methods according to AEDS are substantiated sufficiently.

\section{Shakedown of threaded joints}

Because of prominent mechanical and thermal effect, there is a tendency for formation in the structural element of low-cycle fatigue cracks or accumulation of permanent strains. In this case the parameters of a variable non-elastic straining process tend to limit a projected long-service life of such an element. The fact that permanent stresses, occurring at the beginning of a loading process due to a plastic flow, are found, following a certain number of cycles, not to accumulate any longer, proves that a shakedown of the structure with respect to a given load has already taken place. 
Rated Norms of the RF make provisions for calculation of shakedowns within shells, piping and plates because of the effect of various factors: mechanical loads, temperature (including its variation within the structure), modalities of a geometrical configuration of the element, thermal variations of material properties and radiation. Unfortunately, such a calculation procedure is not adapted to threaded joints, wedges, plugs, etc.

In order to estimate the stability of joints under cyclic loading conditions and limit state leading to possible accumulation of plastic strains, measures have been taken, following theories of shakedown, to analyse the joints that have passed pilot tests. The shakedown conditions specified for such elements, the long-service life of which is determined by calculation of a relatively small number of load variation cycles may be used as a fracture criterion.

Experimental investigation $[5,13]$ into threaded joints has shown that in some instances total stresses arising due to tightening and cyclic bending efforts tend to reach the plastic area and even to penetrate to a certain depth. Also, it has been observed that following a small number of cycles and subsequent formation of a favourable field of residual stresses, cyclic plastic strains fail to accumulate, ie shakedown of joints take place.

Violation of shakedown conditions may cause either an alternating sign plastic flow (usually of a local character) or one-sided strain accumulation affecting the structural element either in whole or in part.

The approximate methods are widely used in the theory of shakedown. By assuming in advance a "proper" kinematically possible distribution of an increment of plastic deformations, one can determine a parameter of surface effects.

A bolt or a stud as a bar of circular cross-section is effected by constant axial force and symmetrically variable bending moment $-M \leq M_{f} \leq M$.

In the considered problem it is assumed that decomposition mechanism is identical with an elongation of stud:

$$
\Delta u_{i 0}(x, y, z)=\Delta u_{z 0}=\text { const }
$$

accordingly

$$
\Delta \varepsilon_{i j 0}^{\prime \prime}=\Delta \varepsilon_{z 0}^{\prime \prime}=\frac{\Delta u_{z 0}}{l},
$$

here $l$ is characteristic length of stud (the distance between the most loaded points of the nut-stud-nut connection).

Dissipation of energy:

$$
\begin{aligned}
& D=\int_{V} \sigma_{i j^{*}}^{0} \cdot \Delta \varepsilon_{i j 0}^{n} d V=4 \int_{0}^{l} d z \int_{0}^{\frac{d}{2}} d x . \\
& \sqrt{d^{2 / 4}-x^{2}}\left(\sigma_{y}-\frac{M}{I_{x}} y\right) \frac{\Delta u_{z 0}}{l} d y .
\end{aligned}
$$

This equation is solved and the dimensionless parameters $n=\frac{N}{N_{y}}$ and $m=\frac{M}{M_{y}}$ are set.

Finally we receive an equation characterizing the condition of one-side accumulation of plastic deformations:

$$
n+\frac{64}{9 \pi^{2}} m=1 \text { or } n+b m=1 .
$$

The condition of the antisymmetric flow was received by means of putting equal the internal of extent variable stresses to two yield limits:

$$
2 \frac{M}{I_{x}} \frac{d}{2}=2 \sigma_{y} .
$$

Introducing the relative coordinate of the bending moment $m$, we receive:

$$
\frac{32}{6 \pi} m=1
$$

The state of threaded joints $M 48 \times 4$ of steel $38 \times \mathrm{M}$ МФA is shown on the diagram of shakedown in Fig 9.

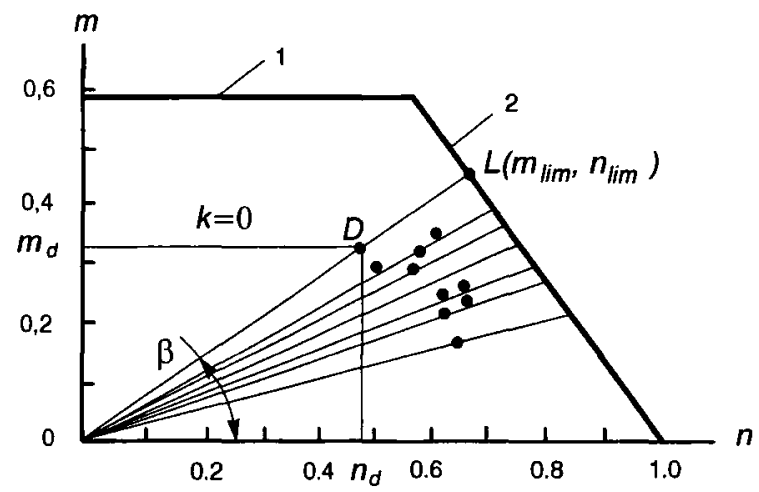

Fig 9. Loading conditions of threaded joints $M 48 \times 4$ on the shakedown diagram: 1 - the condition of the antisymmetric flow; 2 - the condition of one-sided accumulation of plastic deformations; - test data

The point $\mathrm{D}$ with the coordinates $n_{d}$ and $m_{d}$ in the diagram is obtained in those cases when the bolt is loaded with the axial force $N$ and bending moment $M$. The limit point $L$ with coordinates $m_{\mathrm{lim}}$ and $n_{\lim }$ is obtained by means of the radius of similar cycles, the inclination angle of which:

$$
\operatorname{tg} \beta=\frac{m_{\mathrm{lim}}}{n_{\lim }} \text { or } \operatorname{tg} \beta=\frac{m_{d}}{n_{d}} .
$$

The reserve coefficient is identified from quotient:

$$
\eta=\frac{m_{\mathrm{lim}}}{m_{d}} \text { or } \eta=\frac{n_{\mathrm{lim}}}{n_{d}},
$$

By using the equation [15] describing a progressive variation of the configuration, one can define the factor of safety as follows: 


$$
\eta=\frac{1}{n_{d}+b m_{d}}
$$

In order to make a statistical evaluation for the progressive variation of the configuration, use can be made of the procedures applicable in the low-cycle fatigue area.

The paper presents the threaded joints shakedown analysis alongside the estimation of the safety margin for progressive variation of the experimentally tested joint configuration and statistical evaluation thereof. For the joints concerned, the factor of safety is found to vary within 1.06 and 1.79 , whereas variations of a probability factor are within the range of $1 \%$ to $99 \%$.

Given the tightening effort is close to $0.8 \sigma_{y}$ (when $\sigma_{y}$ is the yield point and bending effort is $0.4 \sigma_{y}$, the factors of safety for the progressive configuration variations are close to 1 ). It is estimated that such factors of safety in the flexoplastic area are insufficiently reliable. Therefore improvement of methods related to evaluating cyclic strength and shakedown is very urgent, since it will help increase the reliability of objects in the design. Statistical analysis proves that in order to have a reliable description of the safety margin for the progressive variation of the threaded joint configuration, one has to derive the $50 \%$ test curve, which in the current case represents the factor of safety $\eta=1.322$.

\section{Conclusions}

1. An experimental and theoretical investigation into the resistance of threaded joints to low cycle and high cycle loading proves that the existing calculation procedures are insufficiently justified. Therefore, on the basis of the criteria of fracture mechanics and shakedown theories, the methods of the present paper are specified and improved in respect of design, technological and operational parameters.

2. The analytical expression derived and shakedown diagrams developed were used to elaborate a reserve calculation procedure for a progressive profile change in different threaded joints (without any crack; with a unidirectional and bidirectional cracks).

3. In order to develop a uniform cyclic strength and shakedown calculation procedure for critical threaded joints, a completely new calculation of a progressive profile change is recommended to perform before the cyclic strength calculation.

\section{References}

1. Normy rasčeta na pročnost elementov reaktorov, parogeneratorov, sosudov $i$ truboprovodov atomnych elektrostancij, opytnych i issledovatelskich jadernych reaktorov i ustanovok. Moskva: Metallurgija, 1973. 408 p. (in Russian).

2. Normy rasčeta na pročnost oborudovanija i truboprovodov atomnych energetičeskich ustanovok. Moskva: Energoatomizdat, 1989. 525 p. (in Russian).

3. International standard. Threaded fasters. Axial load fatigue testing. Test methods and evaluation of results. ISO 3800: 1993(E). Printed in Switzerland. $17 \mathrm{p}$.
4. Leonavičius M. K. Srieginiu jungčiu ir jungiamu elementu atsparumas cikliniam irimui ir prisitaikomumas. Vilnius: Technika, 1999. $97 \mathrm{p}$.

5. Leonavičius M. K., Speičys A. A. Soprotivlenije cikličeskomu osevomu-izgibnomu deformirovaniju rezbovych soedinenij. Tezisy dokladov $i$ soobšenij $V$ vsesojuznogo cimpoziuma „Malociklovaja ustalost - kriteriji razrusenija $i$ struktura materialov". Volgograd, 1987, p. 194-196 (in Russian).

6. Kononov B., Leonavičius M. K., Šukšta M., Filatov B. Primenenije statičeskoj i kinematičeskoj teorem dlia ocenki prisposobliajemosti rezbovych sojedinenij. Mechanine technologija, XXI. Kaunas: Technologija, 1993, p. 211219 (in Russian).

7. Leonavičius M. , Krenevičius A. Prisitaikomumo ir atsparumo mažacikliam irimui varžtinese jungtyse skaičiavimas. Mechanika, Nr. 1. Kaunas, 1995, p. 30-32.

8. Filatov V., Leonavičius M. K. Rascet na pročnost rezbovych soedinenij komponentov ASU. Trudy IV meždunarodnoj konferenciji „Problemy materialov pri izgotovleniji i ekspluataciji AES“. Vol 3. Sankt-Peterburg, 1966, p. 141155 (in Russian).

9. Leonavičius M., Šukšta M., Kononov V. Varžto kintamo tekejjimo ir progresuojančio irimo salygu patikslinimas. 4-osios tarpt. konf. „, Naujos statybinès medžiagos, konstrukcijos ir technologijos", ivykusios Vilniuje $1995 \mathrm{~m}$. gegužès 10-13 d., straipsniai. III tomas. Vilnius: Technika, 1995, p. 226-230.

10. Leonavičius M., Šukšta $M$. The bolt with a crack shakedown estimation by the method of additional load. Statyba, 1997, No 1(9). Vilnius: Technika, 1997, p. 74-77.

11. Filatov V. M., Krenevičius A. I., Leonavičius M. K. V., Speičys A. A. Rascet na pročnost rezbovogo AEU. Trudy $V$ meždunarodnoj konferenciji „, Materialovedčeskije problemy pri projektirovaniji, izgotovleniji i ekspluataciji oborudovanija AES“. Sankt-Peterburg, 1998, p. 201-221 (in Russian).

12. Leonavičius M., Stupak S. Itempimų būvio ịtaka plyšio susidarymui sriegio iduboje. Mechanika, Nr. 2. Kaunas: Technologija, 1998, p. 5-9.

13. Leonavičius $M$. and Krenevičius A. Shakedown and Failure of the Threaded Joints under Low Cyclic Loading. Journal of Counstructional Steel Research, Vol 46, 1998 / The Steel Counstruction Institute. Elsevier, p. 452-453. Special issue on CDROM.

14. ASME Boiler and Pressure Vessel Code, Sec. III. Rules for Construction of Nuclear Power Plant Components, Div. I., Subsec. NB, 1995, p. 87-92.

15. ASME Boiler and Pressure Vessel Code, Sec. III. Rules for Construction of Nuclear Power Plant Components, Div. I., Appendices, 1995, p. 6-12.

16. Bazaras $\check{Z}$. and Leonavičius $M$. Evaluation of the threaded joint progressing accumulation of deformation. Mechanika, Nr. 2. Kaunas: Technologija, 2000, p. 13-17.

17. Peeker E., Niemi E. Fatigue crack propagation model based on a local strain approach. Journal of Constructional Steel Research, 49(1999), p. 139-155.

18. Hertzberg R. W. Deformation and fracture mechanics of engineering materials. John Willey \&Sons, Inc. New YorkSingapore, 1996. $786 \mathrm{p}$. 